\title{
Analisis Kesulitan Guru Paud dalam Membelajarakan IPA pada Anak Usia Dini
}

\author{
Dyah Setyaningrum Winarni \\ Pendidikan IPA \\ IKIP Veteran Jawa Tengah \\ email: dyahsetya23@gmail.com
}

\begin{abstract}
Abstrak
Pendidikan anak usia dini (PAUD) sebagai dasar pendidikan anak yang lebih tinggi dan menyiapkan generasi pembelajar yang memilki jiwa kompetisi yang sehat sangat penting. Hal tersebut bisa dilakukan melalui pembelajaran sains. Penelitian ini menganalisis kesulitan guru PAUD dalam membelajarkan sains pada anak usia dini. Metode yang digunakan deskriptif kualitatif dengan sampel 35 orang guru PAUD di Kecamatan Tegowanu, Kabupaten Grobogan, Jawa Tengah. Data yang diperoleh dianalisis menggunakan teknik informant review atau umpan balik dari informan oleh Milles dan Hubberman. Untuk menjamin validitas data yang dikumpulkan juga menggunakan teknik triangulasi. Hasil penelitian menunjukkan bahwa kesulitan guru PAUD dalam membelajarkan sains pemahaman konsep sains yang masih kaku dengan mengikuti buku acuan, keterbatasan alat, bahan, dan waktu, serta penerapan konsep sains yang belum mengacu pada lingkungan anak usia dini. Berdasarkan hasil penelitian tersebut, maka dapat disimpulkan bahwa kompetensi guru PAUD harus ditingkatkan sesuai dengan tujuan membelajarkan sains pada anak usia dini.
\end{abstract}

Kata kunci: pendidikan nak usia dini, sains, kesulitan guru PAUD

\begin{abstract}
Early childhood education (ECD) as the basis for higher education of children and prepare the next generation of learners who have the spirit of healthy competition is very important. This can be done through science lessons. This study analyzes the difficulties of early childhood teachers in teaching science in early childhood. The method used was descriptive qualitative with sample 35 early childhood teachers in the Tegowanu, Grobogan, Central Java as the sample. The data were analyzed using the technique of informant reviews or feedback from informants by Milles and Hubberman. To ensure the validity of the data collected triangulation techniques were also used. The results show that the early childhood teachers were facing the difficulties in teaching the concept understanding by using the reference book, limited media, materials, and time, as well as the application of science concepts which is not appropriate for early childhood environment. Based on these results, it can be concluded that the competency of early childhood teachers must be improved in accordance with the purpose of teaching science in early childhood.
\end{abstract}

Keywords: early childhood education, science, the difficulty of early childhood teachers 


\section{PENDAHULUAN}

Pendidikan anak usia dini (PAUD) sudah mulai dicanangkan oleh pemerintah. Berdasarkan kurikulum 2004 Taman Kanak-Kanak bahwa pendidikan anak usia dini merupakan suatu upaya pembinaan yang ditujukan kepada anak usia dini yang dilakukan dengan memberikan rangsangan pendidikan untuk membantu pertumbuhan dan perkembangan jasmani dan rohani. Dengan upaya seperti ini anak diharapkan memiliki kesiapan dalam memasuki jenjang pendidikan yang lebih tinggi. Pengenalan berbagai macam bidang pendidikan akan mampu merangsang anak dalam memahami dan menjadi acuan bakat yang dimiliki.

Bidang pendidikan yang harus dikenalkan kepada anak usia dini diantaranya adalah sains. Pengenalan sains untuk anak pra sekolah lebih ditekankan pada proses daripada produk. Sains bukan berisikan rumusan atau teori-teori yang kering melainkan juga mengandung nilai-nilai manusiawi yang bersifat universal dan layak dikembangkan serta dimiliki oleh setiap individu di dunia bahkan dengan bagitu nilai sains bagi kehidupan menyebabkan pembekalan sains yang dapat diberikan sejak usia anak masih dini.

Anak usia prasekolah memiliki keterampilan proses sains yang hendaknya dilakukan secara sederhana dan sambil bermain. Kegiatan sains yang diajarkan memungkinkan anak melakukan eksplorasi terhadap berbagai benda, baik benda hidup maupun benda tak hidup yang ada disekitarnya. Anak belajar menemukan gejala benda dan gejala peristiwa dari benda-benda yang ada tersebut. Di sini ada keterkaitan langsung antara pendidik dan peserta didik berlangsung sehingga dipastikan bahwa hasil pendidikan juga tergantung dari perilaku pendidik dan perilaku anak sebagai peserta didik. Dengan demikian dapat diyakini bahwa perubahan hanya akan terjadi jika terjadi perubahan perilaku pendidik dan peserta didik. Oleh karena itu posisi pengajar dan peserta didik sangat strategis dalam meningkatkan kualitas pembelajaran (Surakhmad, 2000: 31).

Proses sains bagi anak-anak dapat menghantarkan menuju seorang sainstis yang hebat. Misalnya anak yang berpotensi untuk menjadi seorang sainstis karena anak dilengkapi dengan kemampuan dan penalaran untuk menempuh pengalaman-pengalaman sains. Dengan segala potensi yang dimiliki oleh anak, seorang guru harus senantiasa dekat dengan anak secara individual serta memberikan wawasan lebih luas, lebih kaya pengalaman, dan lebih kuat dibandingkan dengan kehidupan dan keadaan anak-anak. Guru sebagai fasilitator ditunjuk untuk mendorong agar anak dapat mempelajari sains secara benar, mengingat semua yang sedang dan telah dipelajarinya dengan lebih baik.

Pengembangan pembelajaran sains akan berkembang dengan baik jika guru mampu mengindividualisasikan sains pada anak secara baik yaitu menjadi sifat pribadi melekat pada kehidupannya, berkembang sesuai karakteristiknya serta sesuai dengan 
kesanggupan anak. Untuk mencapai kesempurnaan, guru harus mengenalkan sains pada anak dengan mencocokkan atau mendekatkan suatu kebenaran dalam sistem pengetahuan anak. Tujuan pendidikan sains sejalan dengan tujuan kurikulum sekolah bagi anak usia dini yaitu, mengembangkan anak secara utuh dalam pikirannya, hatinya maupun jasmaninya atau mengembangkan intelektual, emosional dan fisik jasmani maupun dari segi kognitif, afektif dan psikomotorik anak. Oleh karena itu tujuan yang mendasar dari pendidikan sains adalah untuk mengembangkan individu yang peduli terhadap rlingkungan serta mampu menggunakan aspek fundamentalnya dalam memecahkan masalah yang dihadapinya.

Leeper 2002, (dalam Nugraha 2008: 55) dengan pengembangan pembelajaran sains anak usia dini ditujukan untuk merealisasikan pengembangan pembelajaran sains yang diharapkan mampu meningkatkan kecerdasan dan pemahaman anak tentang alam beserta isinya. Untuk itu guru harus membelajarkan sains sesuai dengan konsep sains yang benar bagi anak usia dini.

Penelitian ini menganalisis kesulitan guru PAUD di Kecamatan Tegowanu, Grobogan dalam mengajarkan sains pada anak usia dini. Pemilihan guru PAUD di Tegowanu karena kecamatan tersebut menjadi tolok ukur keterampilan guru PAUD di Kabupaten Grobogan. Selain menganalisis kesulitan guru PAUD dalam mengajarkan sains, melalui penelitian ini ditemukan pula cara mengatasi permasalahan tersebut.

\section{KONSEP PENDIDIKAN ANAK USIA DINI (PAUD)}

Tumbuh kembang anak pada usia dini merupakan usia emas (golden age) yang sangat rentang dalam berbagai situasi dan kondisi yang ada di lingkungannya. Pada usia ini perkembangan dan pertumbuhan anak, baik fisik, psikis, emosional, sosial, maupun bahasanya. Beberapa faktor dapat mempengaruhi perkembangan anak, seperti keluarga, lingkungan, maupun masyarakat dimana orang tua dan anak tersebut tinggal. Untuk itu dalam pengelolaan PAUD memperhatikan aspek-aspek manajeman professional (planning, organizing, actuating, and controlling) dapat memberikan kontribusi signifikan dalam upaya mengantarkan masa perkembangan usia emas anak secara optimal.

Aspek-aspek yang diberlakukan dalam membelajarkann anak usia dini harus sejalan dengan konsep dasar perkembangan anak usia dini. Dalam perkembangan anak pada usia 0-8 tahun perkembangan fisik dan mental yang sangat berkembang pesat, anak memasuki dunia dengan pengetahuan, kemampuan motorik yang mengejutkan, dan kemampuan social dalam berinteraksi dengan orang disekitarnya, serta kemampuan untuk belajar. Konsep pendidikan anak usia dini yang sejalan dengan pola perkembangannya inilah yang diterapkan dalam pendidikan anak usia dini di Indonesia. 
Anak akan mampu berkembang secara optimal, memerlukan penanganan pendidikan anak usia dini yang disertai dengan pemahaman tentang menstimulasi anak, atau cara memberikan kesempatan belajar anak. Dalam bukunya, Aswin (2003: 28) menjelaskan tentang pembagian empat area perkembangan yang harus ditingkatkan dalam kegiatan pendidikan dan perkembangan anak usia dini, yaitu: 1) Perkembangan fisik anak, yang bertujuan supaya anak mampu mengendalikan atau mengontrol gerakan kasar secara sadar dan untuk menstimulus keseimbangannya dalam mengontrol gerakan halus, 2) perkembangan kognitif anak, yang bertujuan supaya anak dapat belajar memecahkan masalah yang dihadapi dan berpikir logis, 3) perkembangan sosial emosional, yang bertujuan untuk memahami diri serta kaitannya yang berhubungan dengan orang lain yaitu teman sebaya dan orang dewasa, bertanggung jawab terhadap diri sendiri maupun orang lain, serta berperilaku sesuai dengan perilaku social secara umum, 4) perkembangan bahasa anak, yang bertujuan supaya anak mampu mendengarkan secara aktif dan berkomunikasi secara benar dengan menggunakan bahasa dan memahami bahwa segala sesuatu dapat diwakilkan dengan tulisan serta dapat dibaca yaitu dengan mengenal abjad, menulis angka dan huruf. Berdasarkan teori tersebut maka sains berperan dalam mengembangkan kemampuan anak dalam berpikir logis, berekspresi, dan memecahkan masalah, yang tentunya akan memberikan dampak positip bagi perkembangan motoriknya.

\section{SAINS DALAM PEMBELAJARAN ANAK USIA DINI}

Sekolah sebagai salah satu tempat yang sangat berperan dalam menerapkan pendidikan karakter yang akan berpengaruh pada perkembangan anak kedepannya. Kurikulum 2004 tentang Taman Kanak-Kanak bahwa pendidikan anak usia dini merupakan suatu upaya pembinaan yang ditujukan kepada anak usia dini yang dilakukan dengan memberikan rangsangan pendidikan untuk membantu pertumbuhan dan perkembangan jasmani dan rohani sang anak. Dengan upaya ini, anak diharapkan memiliki kesiapan dalam memasuki jenjang pendidikan yang lebih tinggi. Pengenalan sains untuk anak pra sekolah lebih ditekankan pada proses dari pada produk dimana anak diajak melakukan kegiatan sain secara sederhana. Dengan cara ini anak belajar menemukan hal-hal baru dari kegiatan sains sederhana tersebut.

Sains juga melatih anak menggunakan lima inderanya untuk mengenal berbagai gejala benda dan gejala peristiwa. Anak dilatih untuk melihat, meraba, membau, merasakan dan mendengar. Semakin banyak keterlibatan indera dalam belajar, anak semakin memahami apa yang dipelajari. Anak memperoleh pengetahuan baru hasil penginderaanya dengan berbagai benda yang ada disekitarnya. Pengetahuan yang diperolehnya akan berguna sebagai modal berpikir lanjut. Melalui proses sains, anak dapat 
melakukan percobaan sederhana. Percobaan tersebut melatih anak menghubungkan sebab dan akibat dari suatu perlakuan sehingga melatih anak berpikir logis. Anak usia dini adalah anak yang sedang membutuhkan upaya-upaya pendidikan untuk mencapai optimalisasi semua aspek perkembangan baik perkembangan fisik maupun psikis yang meliputi perkembangan intelektual, bahasa, motorik dan emosional.

Proses pembelajaran sains, anak juga berlatih menggunakan alat ukur untuk melakukan pengukuran. Alat ukur tersebut dimulai dari alat ukur nonstandar, seperti jengkal, depa atau kaki. Selanjutnya anak berlatih menggunakan alat ukur standar. Anak secara bertahap berlatih menggunakan satuan yang memudahkan mereka untuk berfikir secara logis dan rasional. Dengan demikian sains juga mengembangkan kemampuan intelektual anak. Karena dunia anak adalah bermain maka pembelajaran dapat dilakukan melalui kegiatan bermain sambil belajar atau belajar seraya bermain. Menurut Sudono (2000:1) bahwa kegiatan bermain dalam dunia anak adalah suatu kegiatan yang dilakukan dengan atau tanpa mempergunakan alat untuk menghasilkan pengertian atau memberikan informasi tertentu, memberi kesenangan maupun mengembangkan imajinasi dalam diri anak. Melalui bermain anak diajak untuk bereksplorasi, menemukan dan memanfaatkan objek- objek yang dekat dengannya, sehingga pembelajaran menjadi lebih bermakna. Selain itu, belajar dengan bermain memberi kesempatan kepada anak untuk memanipulasi, mengulang, menemukan sendiri, mempraktekkan dan mendapatkan bermacam-macam konsep.

Anak usia dini atau usia prasekolah, berada dalam masa emas perkembangan otaknya. Salah satu hasil penelitian menyebutkan, kapasitas kecerdasan anak pada usia empat tahun sudah mencapai $50 \%$. Kapasitas ini akan meningkat hingga $80 \%$ pada usia delapan tahun. Ini menunjukkan pentingnya memberi rangsangan pada anak usia dini. Mengenalkan sains pada anak harus sesuai dengan tahapan umur dan perkembangannya. Sebagian besar waktu dari anak usia dini dihabiskan bersama orang tua. Maka yang perlu dilakukan orang tua adalah meluangkan sedikit waktu untuk bermain dengan anak. Dalam situasi bermain itulah kita dapat melakukan eksperimen sains dan mengenalkan matematika yang merupakan tuntutan dan kebutuhan esensial bagi anak usia dini. Dengan bermain, anak dapat memuaskan tuntutan dan kebutuhan perkembangan dimensi motorik, kognitif, kreativitas, bahasa, emosi, nilai, dan sikap hidup.

Pembelajaran sains pada anak usia dini memiliki tahap-tahap perkembangannya anatara lain seperti yang dikemukaan Sujiono (2008: 12) bahwa tahapan pengembangan sains pada anak usia 4-5 tahun adalah mengerti tentang banyak hal seperti informasi yang berhubungan dengan kejadian yang ada disekitarnya. Secara umum anak-anak lebih menyukai percobaan-percobaan dengan bantuan orang dewasa. Anak mulai mampu 
menyeleksi aktivitas yang dilakukan melalui perkiraan terhadap peristiwa yang akan terjadi. Menikmati percakapan dengan teman sebaya seperti bermain dan melakukan percobaan, belajar kata-kata baru dan bermain dengan bahasa. Menggunakan gambaran untuk mewakili dan mengungkapkan ide-ide. Senang melihat buku-buku dan pura-pura membacanya kemudian mengatakan tentang isinya berdasarkan karangannya sendiri. Anak juga lebih menyukai gambar-gambar yang nyata dan jelas gambarnya.

Membelajarakan sains menjadi penting bagi anak usia dini karena membantu anak aktif mencari informasi untuk memenuhi rasa ingin tahu melalui eksplorasi anak akan mampu memahami yang namanya dunia pengamatan. Setiap perubahan-perubahan yang terjadi di sekitarnya, seperti perubahan antara pagi, siang dan malam ataupun perubahan dari benda padat menjadi cair. Melakukan percobaan-percobaan sederhana, seperti biji buah yang ditanam akan tumbuh atau percobaan pada balon yang diisi gas akan terbang bila dilepaskan ke udara. Meningkatkan kreativitas dan pembaruan sehingga anak akan dapat memecahkan masalah yang dihadapinya.

Leeper 2002, (dalam Nugraha 2008: 55) mengatakan bahwa tujuan pembelajaran sains bagi anak usia dini adalah sebagai berikut: (1) supaya anak-anak memiliki kemampuan memecahkan masalah yang dihadapinya melalui penggunaan metode sains, misalnya anak dapat memecahkan masalah mengapa kacang hijau tumbuh di tanah, mengapa kacang hijau membutuhkan air dan sinar matahari, bagaimana jika tanaman kacang hijau tidak diberi air dan sinar matahari; (2) supaya anak memiliki sikap ilmiah. Halhal yang mendasar, misalnya: tidak cepat-cepat dalam mengambil keputusan, dapat melihat sesuatu dari berbagai sudut pandang, berhati-hati terhadap informasi yang diterimanya serta bersifat terbuka; (3) supaya anak-anak mendapatkan pengetahuan dan informasi ilmiah yang lebih baik dan dapat dipercaya, artinya informasi yang diperoleh anak berdasarkan pada standar keilmuan yang semestinya, karena informasi yang disajikan merupakan hasil temuan dan rumusan yang obyektif sesuai dengan kaidah-kaidah keilmuan yang menaunginya; (4) supaya anak lebih berminat dan tertarik untuk menghayati sains yang berada dan ditemukan di lingkungan dan alam sekitarnya.

Ruang lingkup program pembelajaran sains untuk anak usia dini meliputi: (1) materi yang terkait dengan bumi dan jagat raya (ilmu bumi), topik umum untuk pembelajaran pada anak, biasanya meliputi pengetahuan tentang bintang, matahari dan planet, tentang tanah, batuan dan pegunungan, serta kajian tentang cuaca atau musim; (2) materi yang terkait dengan ilmu hayati (biologi), menggambarkan program sains yang meliputi studi tentang tumbuh - tumbuhan, studi tentang binatang atau hewan, studi tentang hubungan antara tumbuhan dan hewan, serta studi tentang hubungan antara aspek-aspek kehidupan dengan lingkungannya; (3) bahan kajian yang terkait dengan ilmu 
- ilmu fisika dan kimia, meliputi studi tentang daya, studi tentang energi, serta studi tentang rangkaian dan raksi kimiawi.

Program pembelajaran sains terkait dengan pengembangan sikap - sikap sains. Diarahkan pada penguasaan sikap yang mencerminkan seorang ilmuwan. Diantara pembentukan sikap sains yang dapat dikembangkan dan diprogramkan adalah sikap rasa tanggung jawab, rasa ingin tahu, disiplin, tekun, jujur dan terbuka terhadap pendapat orang lain. Permainan sains bermanfaat bagi anak karena dapat menciptakan suasana yang menyenangkan serta dapat menimbulkan imajinasi-imajinasi pada anak yang pada akhirnya dapat menambah pengetahuan anak (Sujiono, 2008: 12).

Pengaruh kegiatan sains bagi perkembangan anak adalah pada setiap pertambahan dan perkembangan anak memiliki karakteristik yang berbeda dalam melakukan kegiatan-kegiatan sains. Yang harus diketahui adalah bahwa semua kegiatan sains hendaknya dapat menstimulasi kegiatan belajar kognitif anak. Pada umumnya kemampuan anak untuk bekerja sama muncul secara alamiah ketika mereka terlibat dalam aktivitas kelompok. Perkembangan emosional dalam penjelajahan dan penemuan ilmu pengetahuan sangat berpotensi mengembangkan rasa bangga dan saling menghargai. Melalui penjelajahan sains akan muncul berbagai rasa keheranan dan atau menambah rasa kegembiraan anak-anak sebagai ungkapan sepenuhnya rasa keingintahuan mereka.

\section{METODE PENELITIAN}

Penelitian ini menggunakan metode deskriptif kualitatif. Data yang dikumpulkan berupa data deskripsi tentang kesulitan yang dihadapi oleh guru-guru PAUD. Data yang dikumpulkan dituangkan dalam bentuk laporan uraian sehingga terlihat kesulitan apa saja yang banyak dihadapi guru PAUD dalam membelajarkan sains. Subjek penelitian ini diambil dari guru PAUD yang ada di Kecamatan Tegowanu, Kabupaten Grobogan sebanyak 35 orang tahun ajaran 2016/2017. Teknik penelitian ini adalah purposiv sampling, yaitu teknik pengambilan sampel yang sesuai dengan ciri-ciri dalam karakteristik penelitian yang dilakukan.

Prosedur pengambilan data dengan melakukan wawancara, observasi, dan dokumentasi terhadap setiap subjek penelitian. Instrumen menggunakan pedoman wawancara dan observasi. Pemeriksaan keabsahan data dilakukan dengan triangulasi data. Teknik analisis data kualitatif Milles and Hubberman yang terdiri dari pengumpulan data, reduksi data, penyajian data, dan pengambilan simpulan. Penelitian ini menggunakan teknik informant review atau umpan balik dari informan (Milles dan Hubberman, 1992:453). Untuk menjamin validitas data yang dikumpulkan juga menggunakan teknik triangulasi untuk lebih memvalidkan data. Teknik triangulasi yang peneliti gunakan dalam penelitian 
ini adalah triangulasi sumber, triangulasi metode, dan triangulasi teori. Pertama, triangulasi sumber, yakni mengumpulkan data sejenis dari beberapa sumber data yang berbeda. Kedua, triangulasi metode, yakni mengumpulkan data yang sejenis dengan menggunakan teknik atau pengumpulan data yang berbeda. Dalam hal ini untuk memperoleh data, maka digunakan beberapa sumber dari hasil wawancara dan observasi. Ketiga, triangulasi teori untuk mengintepretasikan data yang sejenis. Data tentang pembelajaran sejarah misalnya, digali dari beberapa teori baik teori pendidikan, psikologi, maupun teori lain.

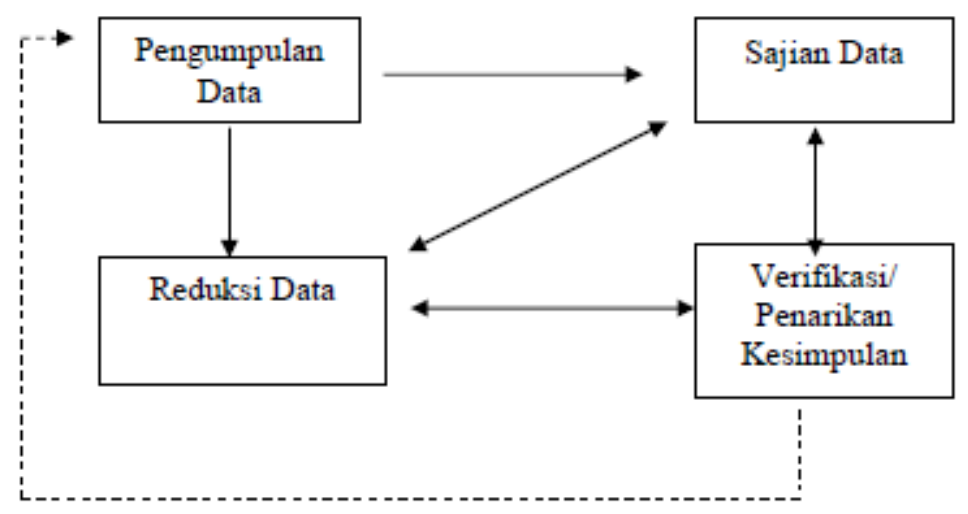

Gambar 1. Model Analisis Interaktif Milles dan Hubberman.

\section{HASIL PENELITIAN DAN PEMBAHASAN}

Salah satu faktor yang dapat mempengaruhi kualitas pembelajaran adalah guru. Kemampuan dalam menyampaikan materi ini akan berdampak pada kualitas pembelajaran yang diajarkan pada siswa. Begitu juga pembelajaran pada anak usia dini. Guru PAUD hendaknya menguasai makna atau arti dari konsep pembelajaran, terutama pembelajaran sains. Selama ini guru PAUD menganggap membelajarkan sains cukup anak tahu apa itu tumbuhan, hewan, tanpa mengetahui makna yang terkandung di alam. Selain itu keterbatasan jumlah guru dibandingkan jumlah siswa yang harus didampingi tidak relevan untuk dilakukan pembelajaran kelompok yang sesuai dengan tuntutan kurikulum.

Hasil analisis deskriptif, data yang diperoleh menunjukkan bahwa pada anak usia dini adalah sesuatu yang sulit dan sedikit berbahaya di usianya yang masih dini. Dari perhitungan rerata guru menjawab hampir $65 \%$ guru kurang memahami makna sains bagi anak usia dini dan $75 \%$ guru menjawab bahwa dalam kurun waktu satu bulan hanya satu atau dua kali pembelajaran sains dilakukan. Dengan data tersebut dapat diketahui bahwa guru tidak membelajarkan sains secara maksimal kepada peserta didik sebagai dampak kurang memahami pembelajaran sains yang diterapkan.

Hasil observasi dalam kelas, penguasaan materi pelajaran dalam membelajarkan sains serta keterampilan menunjukkan beberapa guru kurang memahami cara-cara membelajarkan sains pada anak usia dini. Wawancara dengan guru dan perilaku mengajar 19 | EduSains: Jurnal Pendidikan Sains \& Matematika, Vol.5 No.1; 2017 
di dalam kelas, guru belum secara maksimal menggunakan imajenasi anak usia dini sebagai objek pembelajaran sains. Meskipun inovasi sudah dilakukan kesulitan yang lain yang dihadapi guru berdasarkan hasil wawancara adalah ketersediaan alat dan bahan serta keterbatasan waktu. Dalam membelajarkan sains guru PAUD terpaku pada materi yang diterima ketika guru tersebut duduk dibangku sekolah atau perguruan tinggi.

Keterampilan guru PAUD dalam melihat sekitar dan mengkaitkannya dengan sains masih kurang memadai. Hal ini diperkuat dari analisis deskriptif yang dilakukan bahwa hampir 50\% guru kesulitan mengajarakan sains karena keterbatasan waktu dalam melakukan kegiatan sains. Konsep pebelajaran sains dapat dilakukan dengan kegiatan kecil yang ada di rumah dapat dijadikan sebagi contoh dalam membelajarkan sains, seperti kegiatan makan, minum, mencuci, bahkan bermain. Kegiatan mengajar sains pada guru PAUD yang masih terpaku pada contoh yang ada di buku sehingga menjadikan guru kesulitan dalam membelajarkan sains. Karena pada beberapa buku acuan yang digunakan guru, terkadang alat maupun bahan yang dicantumkan dalam buku belum tentu ada di sekolah maupun di suatu daerah lainnya. Konsep pembalajaran pada PAUD adalah bermain. Hal ini sesuai dengan penelitian Agustini at all (2016) bahwa sains yang dibelajarkan pada anak prasekolah bermanfaat dalam menciptakan suasana menyenangkan serta menimbulkan imajinasi-imajinasi pada anak yang lebih berkembang.

Kesulitan lain yang dihadapi guru adalah kontrol dalam kegiatan pembelajaran sains. Dari hasil wawancara guru menjelaskan kesulitannya dalam mengatur siswa mengikuti kegiatan sains. Apalagi jika satu guru harus mengontrol lebih dari 10 siswa dalam satu kelompok belajar. Oleh karena itu guru cenderung menerapkan sains sebagai pembelajaran tambahan yang dapat dilakukan, dan juga tidak harus dilakukan.

Kualitas pembelajaran merupakan ukuran yang menunjukkan seberapa tinggi kualitas interaksi antara guru dengan siswa yang terjadi dalam tempat pembelajaran (ruang kelas) untuk mencapai tujuan pembelajaran atau mewujudkan kompetensi tertentu. Interaksi tersebut melibatkan guru dan siswa yang dilakukan dalam lingkungan tertentu dengan dukungan sarana dan prasarana tertentu. Dengan demikian keberhasilan proses pembelajaran atau kualitas pembelajaran sangat bergantung kompetensi guru, kompetensi siswa, fasilitas pembelajaran, lingkungan kelas, dan iklim kelas. Secara lebih spesifik, Direktorat Tenaga Kependidikan, Direktorat Jendral Pendidikan Dasar dan Menengah Departemen Pendidikan Nasional (2003: 89) merumuskan standar Kompetensi guru sebagai berikut: 1) kompetensi pengelolaan pembelajaran yang terdiri atas: penyusunan rencana pembelajaran, pelaksanaan interaksi belajar mengajar, penilaian prestasibelajar peserta didik dan pelaksanaan tindak lanjut hasil penilaian prestasi belajar peserta didik, 2) kompetensi pengembangan profesi, dan 3) kompetensi penguasaan akademik, yang terdiri 
atas pemahaman wawasan kependidikan dan penguasaan kajian akademik. Menurut pasal 28 ayat 3 PP Nomor 19 tahun 2005 tentang Standar Nasional Pendidikan dan pasal 10 ayat 1 UU Nomor 14 tahun 2005 tentang Guru dan Dosen kompetensi guru terdiri dari: a) kompetensi pedagogik; b) kompetensi kepribadian; c) kompetensi profesional; dan, d) kompetensi sosial.

Kompetensi yang dijadikan acuan tersebut tidak semata-mata mutlak harus terpenuhi, kesemuanya akan saling bersinergi untuk dapat dikembangkan menjadi lebih baik. Seperti yang dikemukan dalam hasil penelitian yang dilakukan Agustini (2016: 9) bahwa kemampuan guru dalam mengajar siswa ditubtut untuk lebih kreatif dan imajenatif terutama dalam pembelajaran sains sehingga siswa mampu menolah motoriknya baik motoric halus maupun motorik kasarnya. Kemampuan guru tersebut sebagai salah satu upaya dalam mengatasi permasalahan yang sering muncul tentang bagaimana kompetensi yang harusnya dimiliki siswa khususnya anak usia dini tidak tercapai.

Upaya mengatasi kesulitan kontrol maupun waktu guru melakukan kegiatan sains secara demontrasi, sehingga guru lebih mudah dalam mengawasi siswa melakukan kegiatan sains. Kepercayaan diri siswa akan tumbuh ketika siswa tersebut tertarik untuk melakukan kegiatan sains yang serupa. Kesulitan yang lain dihadapi guru yang patut untuk dikaji adalah sinkronisasi antara pembelajaran yang ada di sekolah dengan kegiatan anak di luar lingkungan sekolah. Oleh karena itu guru harus mampu mengambil sampel kegiatan pembelajaran dari lingkungan dimana anak-anak tersebut tumbuh dan berkembang. Untuk itu mengevaluasi keberhasilan program pembelajaran tidak cukup hanya berdasarkan pada hasil penilaian hasil belajar siswa semata, namun juga memperhatikan hasil penilaian terhadap input serta kualitas pembelajaran itu sendiri.

\section{SIMPULAN}

Hasil penelitian dan pembahasan, dapat disimpulkan bahwa kesulitan guru dalam membelajarakan sains adalah pemahaman konsep sains yang masih kaku mengikuti buku acuan, keterbatasan alat, bahan, dan waktu, serta penerapan konsep sains yang belum mengacu pada lingkungan anak usia dini. Adanya perbedaan kondisi suatu daerah menyebabkan guru tidak mampu mengaplikasikan konsep sains, guru mengajarkan sains pada anak usia dini seperti mengajarkan sains pada anak sekolah dasar. Oleh karena itu kompetensi guru harus ditingkatkan sesuai dengan tujuan membelajarkan sains pada anak usia dini. Pembelajaran sains tidak harus terlihat ilmiah sekali, tetapi cukup dengan mengkaitkan pada kegiatan anak sehari-hari akan lebih mudah dipahami oleh logika dan imajenasi anak usia dini. Dengan begitu konsep sains sudah tertanam dan menjadi pemicu bagi anak untuk lebih bereksplorasi terhadap lingkungan di sekitarnya. 


\section{DAFTAR PUSTAKA}

Agustini, Ketut Setia Adi., I Ketut Gading, dan Luh Ayu Tirtayani. 2016. Pengaruh Metode Pembelajaran Eksperimen terhadap Keterampilan Proses Sains pada Kelompok B Semester II TK Kartika VII-3. e-Journal Pendidikan Anak Usia Dini Universitas Pendidikan Ganesha, Volume 4 No.2: 1-10.

Arikunto, Suharsimi. 2002. Prosedur Penelitian Suatu Pendekatan Praktik. Jakarta: PT. Rineka Cipta.

Aswin, Fauzia. 2003. Psikologi Perkembangan Anak. Jakarta: Depdikbud.

Departemen Pendidikan Nasional. 2007. Pedoman Pembelajaran Bidang Pengembangan Fisik Motorik di Taman Kanak-Kanak. Jakarta: Dirjen Manajemen Pendidikan Dasar dan Menengah.

Miles, M.B. and Huberman, A.M. (1984). Qualitative Data Analysis: A Sourcebook of New Methods. Beverly Hills CA: Sage Publications.

Mulyasa. 2011. Praktik Penelitian Tindakan Kelas. Bandung: Remaja Rosdakarya.

Nugraha, Ali. 2008. Pengembangan Pembelajaran Sains Pada Anak Usia Dini. Bandung.

Sudono, A. 2000. Sumber Belajar dan Alat Permainan. Jakarta: Grasindo.

Sujiono. 2008. Metode Pengembangan Fisik. Jakarta: Universitas Terbuka.

Surakhmad, Winarno. 2000. Pengantar Penelitian IImiah Dasar Metode Teknik. Bandung: Tarsito.

Undang - Undang Nomor 14 Tahun 2005 Tentang Guru dan Dosen. 